\title{
COVID-19 Pandemic and Possible Futures of Adult Online Learning in Higher Education Six Trends That Could Shape the Future
}

\author{
Pandémie de COVID-19 et perspectives d'avenir sur la \\ formation en ligne des adultes en éducation supérieure : \\ Six tendances qui pourraient façonner le futur
}

\section{COVID-19 Pandemia y posibles futuros del aprendizaje en línea de adultos en la educación superior: Seis tendencias que podrían marcar el futuro}

https://doi.org/10.52358/mm.vi8.266

Nicolas Gagnon, EdD student

University of British Columbia, Canada

nicolas.gagnon.1@ulaval.ca

The COVID-19 pandemic has had and will have, profound effects on adult education (Boeren, Roumell \& Roessger, 2020; Kapplinger \& Lichte, 2020) and online learning practices. The impact was unprecedented and led to the largest and quickest transformation of pedagogic practice ever seen in contemporary universities (Brammer \& Clark, 2020). Although it is too soon for a full assessment, the first step is to gain insight into an understanding of the macro trends taking shape inside and outside the walls of institutions and then explore how these trends may affect the future. Against this background, a question arises: How is the COVID19 pandemic shaping the future of adult online learning in higher education? Drawing on adult education and higher education scholarly and practitioner literature published over the last year, the purpose of this paper is threefold: (i) in the context of the COVID-19 pandemic, to 
identify and analyze emerging trends that could shape the future of adult online education in higher education, (ii) to analyze these trends over a longer time span in the literature, and (iii) to explore the possible futures of adult education and online learning in higher education.

Keywords: higher education, online learning, COVID-19, distance learning, adult learning, adult education, lifelong learning

\section{RÉSUMÉ}

Il est inévitable que la pandémie de COVID-19 aura des effets considérables sur l'éducation des adultes (Boeren, Roumell \& Roessger, 2020; Kapplinger \& Lichte, 2020) et les pratiques d'enseignement et d'apprentissage en ligne. L'ampleur du phénomène est historique et a probablement entraîné la transformation la plus importante et la plus rapide des pratiques pédagogiques jamais observée dans les universités contemporaines (Brammer \& Clark, 2020). Bien qu'il soit trop tôt pour en mesurer tous les effets, l'une des premières étapes vers une meilleure compréhension du phénomène consiste à recueillir, à analyser et à mettre en perspective les macro-tendances qui semblent se dessiner à l'horizon. Ainsi, en prenant appui sur la littérature scientifique et professionnelle publiée depuis mars 2020, l'objectif de cet article est triple : (i) dans le contexte de la pandémie de COVID-19, identifier, analyser et mettre en perspective les tendances émergentes qui pourraient façonner l'avenir de l'éducation des adultes en enseignement supérieur, (ii) analyser certaines de ces tendances sur une période allant au-delà de celle couverte par la pandémie, et (iii) poser un regard prospectif sur l'avenir.

Mots-clés : COVID-19, pandémie, éducation supérieure, formation en ligne, formation à distance, éducation des adultes, enseignement supérieur, apprentissage tout au long de la vie

\section{RESUMEN}

Los efectos considerables en la educación de los adultos (Boeren, Roumell \& Roessger, 2020; Kapplinger \& Lichte, 2020) y en las prácticas de enseñanza y aprendizaje en línea de la pandemia COVID-19 son inevitables. La importancia del fenómeno es histórica y ha supuesto seguramente la transformación más importante y más rápida vista hasta ahora de las prácticas pedagógicas en las universidades contemporáneas (Brammer \& Clark, 2020). Aunque es demasiado pronto para considerar todos sus efectos, una de las primeras etapas hacia una mejor comprensión del fenómeno consiste en recoger, analizar y poner en perspectiva las macrotendencias que parecen dibujarse en el horizonte. Así pues, basándose en la literatura científica y profesional publicada desde marzo de 2020, el objetivo de este artículo es triple: (i) en el contexto de la pandemia de COVID-19, identificar, analizar y poner en perspectiva las tendencias emergentes que podrían moldear el futuro de la educación de los adultos en educación superior, (ii) analizar algunas de dichas tendencias durante un período más allá de la pandemia, y (iii) realizar una mirada prospectiva hacia el futuro.

Palabras clave: COVID-19, pandemia, educación superior, formación en línea, formación a distancia, educación de los adultos, enseñanza superior, formación continua 


\section{Introduction}

The COVID-19 pandemic has had, and will have, profound effects on adult education (Boeren, Roumell \& Roessger, 2020; Kapplinger \& Lichte, 2020) and online learning practices. On March 11, 2020, the World Health Organization declared the coronavirus a pandemic. In the following weeks, countries worldwide went into lockdown and much of the world's higher education institutions shifted to remote learning. The impact was unprecedented and led to the largest and quickest transformation of pedagogic practice ever seen in contemporary universities (Brammer \& Clark, 2020).

The year 2020 was one of the most challenging for the higher education sector and one that will likely have far-reaching impacts. A particular challenge was the urgent and unexpected request for pivoting from faceto-face teaching to emergency distance and online instruction (Rapanta et al., 2020), an online pivot that lasted more than 15 months. Although it is too soon for a full assessment, early data and literature reveal emerging trends that could shape the future of online learning in higher education. On the one hand, literature suggests an increased use of learning technologies and a new appreciation-and new expectations-for online education in higher education (Fox et al., 2021; Johnson et al., 2021), which could potentially increase adult lifelong learning opportunities (OECD, 2020). On the other hand, the crisis has laid bare and exacerbated long-standing digital inequities (Pelletier et al., 2021; Fox et al., 2021; Janak, 2020) and political problems in adult education funding (Stanistreet et al., 2020; Kapplinger \& Lichte, 2020).

Against this background, a question arises: How is the COVID-19 pandemic shaping the future of adult online learning in higher education? Drawing on adult education and higher education scholarly and practitioner literature published over the last year, the purpose of this paper is threefold: (i) in the context of the COVID-19 pandemic, to identify and analyze emerging trends that could shape the future of adult online education in higher education, (ii) to analyze these trends over a longer time span in the literature, and (iii) to explore the possible futures of adult education and online learning in higher education.

\section{Six trends that could shape the future}

In seeking to foresee the evolution and the future of online learning and adult education in higher education, the first step is to gain insight into and an understanding of the macro trends taking shape inside and outside the walls of institutions, and then to explore how these trends affect the future.

Without claiming to be exhaustive, this paper highlights and explores some of the key issues identified by practitioners and researchers over the last fifteen months. Below are the six identified trends, most of them (if not all) are not new, but all of them have been accelerated or disrupted by the coronavirus pandemic and overlap each other:

1) The widening of the digital divide.

2) A focal point of interest and concern for equitable online learning.

3) A new appreciation-and new expectations-for online education.

4) An increased use of (some) learning technologies.

5) A preference for online short-term and nondegree credentials, and for skills training options.

6) The adoption of new flexible approaches. 


\section{Widening of the digital divide}

The COVID-19 pandemic has laid bare and exacerbated long-standing digital inequities. For the entire field of education, one of the biggest disparities that COVID-19 has highlighted is access to reliable technology (Pelletier et al., 2021; Kapplinger \& Lichte, 2020; Janak, 2020).

The forced digitalisation of teaching and learning has highlighted key limitations, such as access to even the basic devices and network necessities, and the prerequisite of adequate digital skills. Among higher education institutions, the widening of the digital adds to the challenges already faced by rural residents (Lai \& Widmar, 2021) and international students from developing countries (Esteban, 2021). Furthermore, low-income households and racial/ethnic minorities are the most impacted by unavailability (Ong, 2020).

Since the digital divide limits learning opportunities and digital technologies are becoming an increasingly important component of teaching and learning, there is concern among all education stakeholders regarding issues associated to the digital divide, particularly regarding the fact that the gap will only widen between those who are 'digitally included' and those who are not.

\section{Equitable online learning: a focal point of interest and concern}

It is a well-established fact that certain groups are underrepresented and others overrepresented in the higher education student population, and studies have shown that "fundamental social disparities have proven to be relatively stable" (Stöter et al., 2014). In this regard, during the COVID-19 pandemic, administrators, faculty, practitioners and researchers expressed concerns about the impact of remote teaching on equitable learning opportunities for students.

Worldwide, open and distance learning is being regarded as a promising approach for increasing access to education and the use of limited educational resources (OECD, 2020; Chawinga \& Zozie, 2016). One would therefore expect the open and distance learning student population to yield a higher proportion of students from underrepresented backgrounds. However, when examining a period of time that extends beyond the last year, the reviewed literature reveals that while many governments and higher education institutions promote online education as a way to increase inclusion and reduce barriers to equitable participation in education, these assumptions do not operate with uniformity across all student cohorts. Inequitable learning experiences occur in online education (Öztok, 2019; Gnanadass \& Sanders, 2018; Davis, 2018)-democratizing the mandate of distance education has still not been accomplished (Lee, 2017)-and despite the recent focus on digital accessibility, accessibility has not been achieved among higher education institutions (Davis, 2018).

According to Öztok (2019), the hidden curriculum of online education maintains cultural hegemony and creates inequitable learning experiences through cultural differences. Öztok also argues that inequitable or unfair online learning experiences are not random acts, but rather reflect the existing inequities in society at large. In a similar vein, according to Gnanadass and Sanders (2018), even with the emancipatory goal of online education, socially constructed gender norms and inequities shape online behaviours and interactions. In other words, constructed differences in gender found in traditional educational settings are reproduced online. In this respect, Gnanadass and Sanders also argue that even though distance education has really benefited women, gender inequity still exists, and the specific needs of women are not being taken into account. 
The advancement of technology has had both positive and negative effects for online learners with disabling conditions in higher education. On the one hand, there are forces that propel these learners forward-digitally enhanced pedagogy, universal design for learning, and assistive technologies-and, on the other hand, there are adverse challenges: stigma of assistive technologies, hegemony and entrenched stigma, cost of technologies, inaccessible online learning and electronic learning materials (Kinash et al., 2018). Among the positive aspects of online learning, some students with disabling conditions prefer the de-identified nature of online learning because they feel that online interaction is nearly sanctimonious, as compared to face-to-face (Kinash et al., 2018). Among the problems faced by online learners with disabling conditions is the fact that inaccessible technology is woven into the fabric of the academic experience at many institutions (Davis, 2018). To conclude on this point, it is worth noting that in the period 2015-2016, the Open University UK was the largest provider of UK higher education for people with disabilities, with more than 22,000 students with disabilities enrolled (Baxter et al., 2018), which underlines the importance of adapting distance learning activities and resources to meet the needs of students with disabilities.

In a wider context, the widespread adoption of distance education and educational technologies in higher education are not simply the product of technological evolution. For many scholars, the rise in online education is embedded in the political, economic and social contexts in which neoliberal narratives and practices are dominant (Baxter et al., 2018; Picciano, 2016; Smith et al., 2018), a neoliberal philosophy that also promotes privatization, market-driven approaches and corporate solutions to public services, including higher education (Picciano, 2016). Furthermore, liberal and humanistic values-such as personal development, individual autonomy, equity and access-justifying educational practice are seen to legitimize online learning (Nicoll, 2008). Against this background, online education in higher education is seen by many as a strategy of neoliberal governance, which includes pressures to competition, efficiencydriven development, cost containment measures, expectations of student self-reliance, and expectations of labour flexibility and adaptability. In that regard, Smith et al. (2018) found that "when mobilized as a timesaving measure, online programmes can exacerbate the intensified workload for both teachers and students, and they can also limit potential for equity and inclusion in the university."

In sum, these 'multiple perspectives' have important wider implications. The main point here is that it is one thing to claim that online education has expanded educational opportunities to a greater number of students, and that technology has transformed education in profound ways. But it is quite another thing to claim that online education provides flexibility for all, that it provides opportunities to learn within a fairer learning context, that it increases accessibility and inclusion across all student cohorts, and that it achieves greater equality of opportunities. In that regard, the literature clearly suggests that more critical and nuanced perspectives are needed. This is the case particularly for groups that are underrepresented in post-secondary education, including indigenous populations, low socio-economic groups, first-generation students, single parents, disabled learners, recent immigrants, students in remote communities, and members of minority language groups. 


\section{New appreciation—and new expectations_-for online education}

Online learning in higher education is not a new phenomenon. Well before the pandemic, in 2017, the proportion of American students enrolled in at least one distance learning course was estimated to be 33.1\% (Lederman, 2018). In Canada, according to Donovan and Bates (2018), one in five students (20\%) was enrolled in at least one distance learning course in 2017. Now, though, virtually all teachers and students have had online learning in one form or another imposed on them over the last 15 months. Within this new perspective, early data indicates that students and teachers both seem to have a heightened appreciation for online learning.

From the student perspective, the data indicates that more students are considering online study in the future (Aslanian et al., 2021). An Educause survey (Gierdowski et al., 2020) conducted prior to the COVID19 pandemic found that higher education students' preferred mode of instruction was, for the vast majority $(69 \%)$, completely or mostly face-to-face, followed by hybrid mode $(21 \%)$, and finally, completely or mostly online $(10 \%)$. For purposes of comparison, a survey conducted by Higher Education Strategy Associates (HESA, 2021) in December 2020 among students enrolled in a Canadian university. That survey found that students' preferred mode of instruction was, for the vast majority $(62 \%)$ hybrid, followed by completely or mostly online $(20 \%)$, and finally, completely or mostly face-to-face $(18 \%)$. While recognising that (1) the data does not come from peer-reviewed research articles, (2) the data was not collected using a similar survey instrument, and (3) recent data reflects students' perceptions at a given point in time (while they were mostly confined at home), the preferred mode of instruction will evolve over time. So far, there seems to be a significant shift in student expectations and demand for online learning in higher education.

From the teacher perspective, Fox et al. (2021) examined the ongoing impact of the COVID-19 pandemic on teaching and learning in higher education and found that faculty sentiment about online learning has grown positively throughout the pandemic. According to the study, the increased exposure to digital teaching and learning practices and tools has enabled faculty to experiment new practices, which has positively altered their perception of online learning. Figure 1 illustrates how teacher perception of online learning as an effective method for teaching has evolved-pre-pandemic, in preparation for fall 2020 and in November 2020. 


\section{Figure 1}

Faculty sentiment about online learning

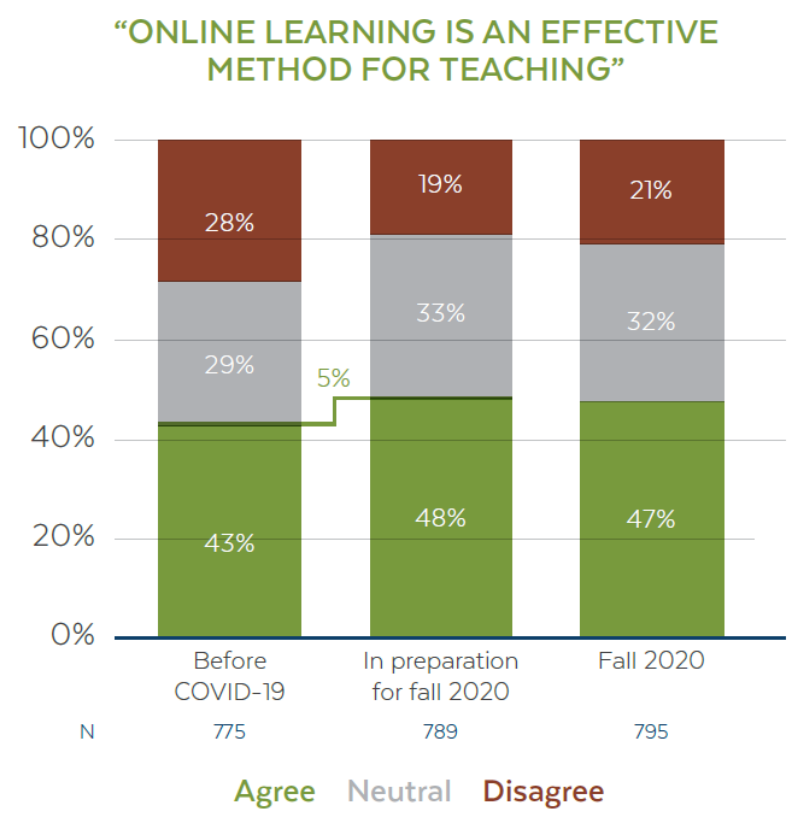

Note. Source: Fox et al. (2021)

In the same vein, Johnson et al. (2021) conducted three United States national surveys ${ }^{1}$ of higher education administrators and teaching faculty over the last year. The surveys show that while a large proportion of faculty had a negative opinion about online learning prior to March 11, 2020, many gained a new appreciation for online learning during the first 10 months of the COVID-19 pandemic. Following the fall semester, faculty opinions about online learning were more optimistic than they were before the pandemic, and administrators had similar optimism levels about online learning.

The surveys also found that compared to teaching prior to the pandemic, most faculty $(71 \%)$ reported changes to their teaching practices, and that faculty expect that teaching will continue to be different following the pandemic. Figure 2 shows that $8 \%$ of faculty who responded to the survey think that their post-pandemic teaching will be very different, $39 \%$ believe it will involve many changes, $41 \%$ expect small changes and $8 \%$ report that they expect their post-pandemic teaching to revert to what it was prepandemic.

\footnotetext{
The first in April 2020, the second in August 2020 and the third December 2020.
} 


\section{Figure 2}

Faculty post-pandemic teaching expectations

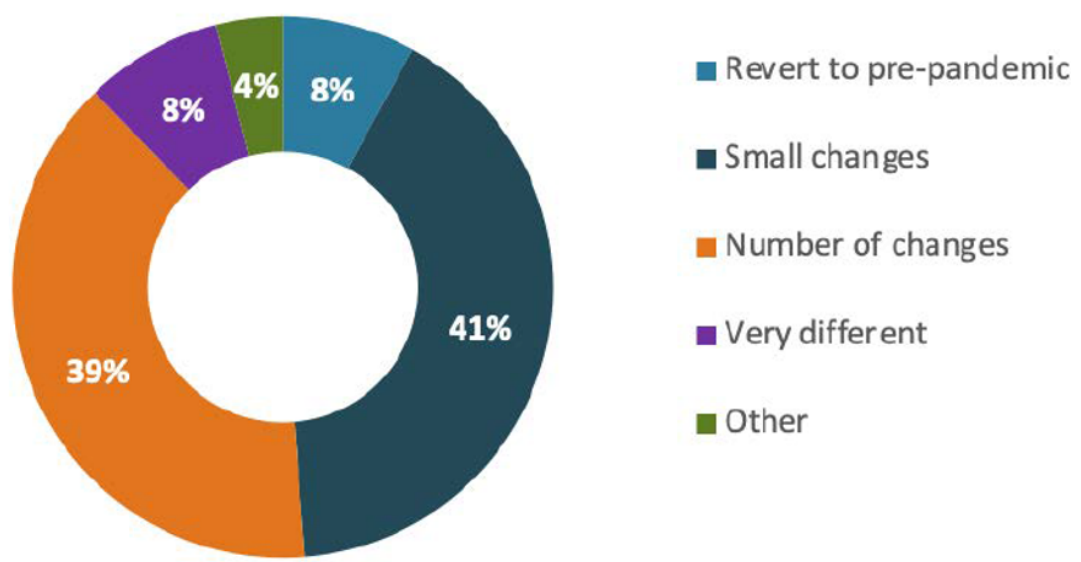

Note. Source: Johnson et al. (2021, p. 39)

\section{Increased use of (some) learning technologies}

The COVID-19 pandemic has advanced digital technologies in teaching and learning. Clearly, the shift to online learning has accelerated the adoption of new learning technologies. However, according to Garrett et al. (2021), the crisis has boosted mainstream adoption of some educational technology tools more than others. In that regard, Figure 3 charts the types of education technologies used, distinguishing pre-COVID-19 pandemic mainstream adoption, net major investment in 2020, and net executed or planned major investment in 2021 (from chief online officers' perspectives). The data shows that video conferencing produced the largest gains, virtual labs and simulations saw the greatest proportional increase, and video recording and distribution and accessibility tools moved into majority territory. 


\section{Figure 3}

Pandemic education technology momentum

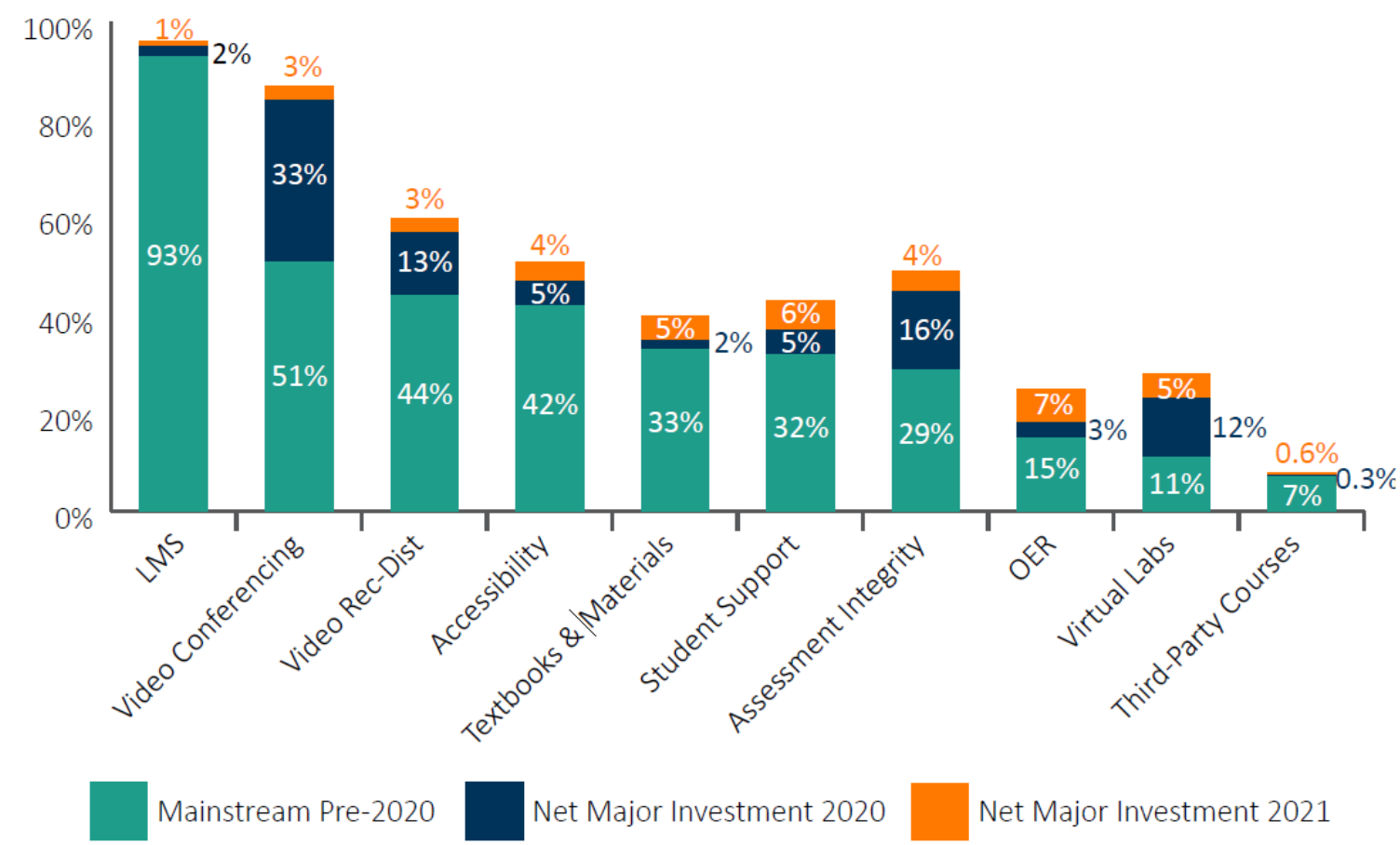

Note. Source: Garrett et al. (2021)

From a broader perspective, since the increased use of learning technologies is still, and will likely be for years to come, a key priority for many institutions, more and better educational technologies will emerge from the crisis. This will also likely lead to a growth in adoption of emerging technologies such as artificial intelligence, learning analytics tools, virtual and augmented reality, and the internet of things.

\section{Preference for online short-term credentials, nondegree credentials and skills training options}

According to Strada, between April and October 2020, a majority (63\%) of Americans 18 and older expressed a consistent preference for nondegree and skills training options (see Fig. 4). Strada's data further shows that $59 \%$ of survey respondents would prefer fully online learning or hybrid learning, even if COVID-19 were not a threat. 


\section{Figure 4}

Preferred education option, Americans ages 18+

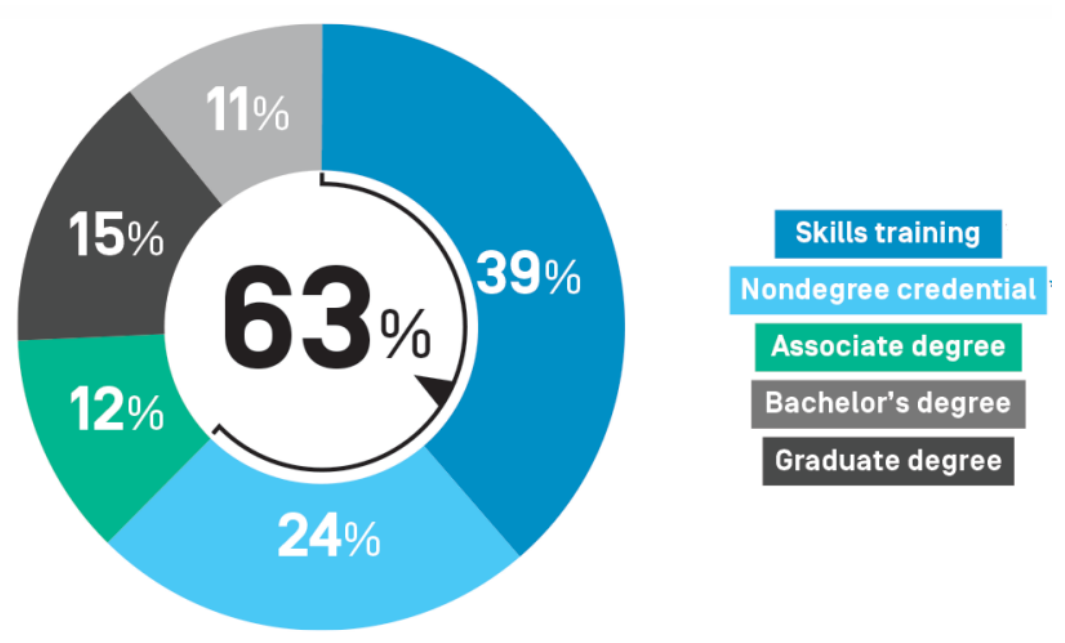

Note. Source: Strada (2020).

Along the same line, according to Freedman and LeBlanc (2021), the population of adults that was deeply disrupted by the pandemic wants short-form programs that are laser-focused on skills. This is accelerating the demand for short-form programs. In that respect, data collected over the last year reveals that more prospective online students are being attracted to short-term credentials, especially those who need job skills quickly or have limited resources (Aslanian et al., 2021).

Providing online skills training, short-term credentials and nondegree credentials to adult learners who are seeking additional skills but not a full degree is not a new phenomenon in higher education. Over the last years, online learning has paved the way for the need for different types of credentialing (Lemoine \& Richardson, 2015), and there has been an emergence and growth of flexible micro-credentials and alternative credentials in higher education (Wheelahan \& Moodie, 2021; Pelletier et al., 2021;). However, despite the growing interest for different types of online credentialing and the high motivation of higher education institutions, before the COVID-19 pandemic, micro-credentials uptake in academic institutions was low across the globe (Ghasia et al., 2019). In view of this, while there are still important challenges remaining to the widespread adoption of new forms of credentialing, the growing demand for online shortterm credentials, nondegree credentials and skills training options will be shaping the future of adult online learning in higher education.

\section{Adoption of new flexible approaches}

While adapting to remote teaching has led to a wide range of creative uses of technologies, the continuity of teaching and learning has relied on more than digital platforms and tools (Johnson et al., 2021). In order to meet diverse student needs and to support student learning and well-being, it has relied on the adoption of more flexible learning approaches, such as adapting course contents, assessments, learning objectives 
and learning activities (Fox et al., 2021). Moreover, emergency remote teaching and physical distancing measures have been powerful forces that have reshaped the learning space, whether physical or virtual, whether formal or informal, through flexible learning environments that allow for a range of teaching methods and classroom configurations (Cahapay, 2020).

For the past three decades, flexibility has been a growing focus of attention and efforts in the field of education (Li \& Wong, 2018). Flexibility in learning has been considered one key to providing lifelong learning opportunity, to increasing accessibility, to enhancing education quality and to engaging with a more heterogeneous student body. With the increasing use of technologies, the concept of flexible learning has been closely associated with concepts such as blended, hybrid-flexible-HyFlex-) and online learning. However, flexible learning is more encompassing than online learning. In order to provide students a variety of choices and ways to learn (Zayabalaradjane, 2020), flexible delivery needs to flex to multiple points or positions (Evans, 2000). This means that the concept of flexible learning includes multiple dimensions, such as time, instructional approach, calendar, assessment, grading, content, learning spaces, entry requirement and goal of the course (Li \& Wong, 2018).

In light of this, forced remote teaching has been a catalyst for exploring and experimenting more flexible models and practices (Rapanta et al., 2020). Adapting to remote teaching during COVID-19 has brought more flexibility to course design and teaching practices, and it is anticipated that flexible learning will be a key part-if not the norm-in post-pandemic education.

\section{How is COVID-19 shaping the future online learning in higher education?}

In the coming years, there will inevitably be a significant increase in the offer of and demand for online education in higher education. Remote teaching has had allowed higher education institutions to explore the possibilities and limits of online and distance learning. Higher education institutions will hence adopt online learning approaches - in one form or another-in a significant way, more than they did before the COVID-19 pandemic. Many things that happen on campus simply cannot happen at a distance. However, online options are here to stay and, in the future, campuses will be neither fully remote nor fully on-site.

Remote teaching and physical distancing measures are powerful forces that have propelled online and flexible learning approaches. These two forces have also propelled digital tool adoption and the demand for online short-term, nondegree credentials and skills training among adult learners. Moreover, teachers and students have developed a new appreciation-and expectation-for online education, and the massive shift to remote teaching has heightened awareness of the digital divide and online learning inequities issues. Though it remains to be seen whether the transformations persist into the future, surely, long-term impacts on tertiary education teaching and learning practices will endure. Traditional and nontraditional students now expect a flexible online learning experience that can replace or complement faceto-face learning experiences. Furthermore, faculty are also demanding flexibility as to when and where they teach. 


\section{Figure 5}

How is COVID-19 shaping the future online learning in higher education?

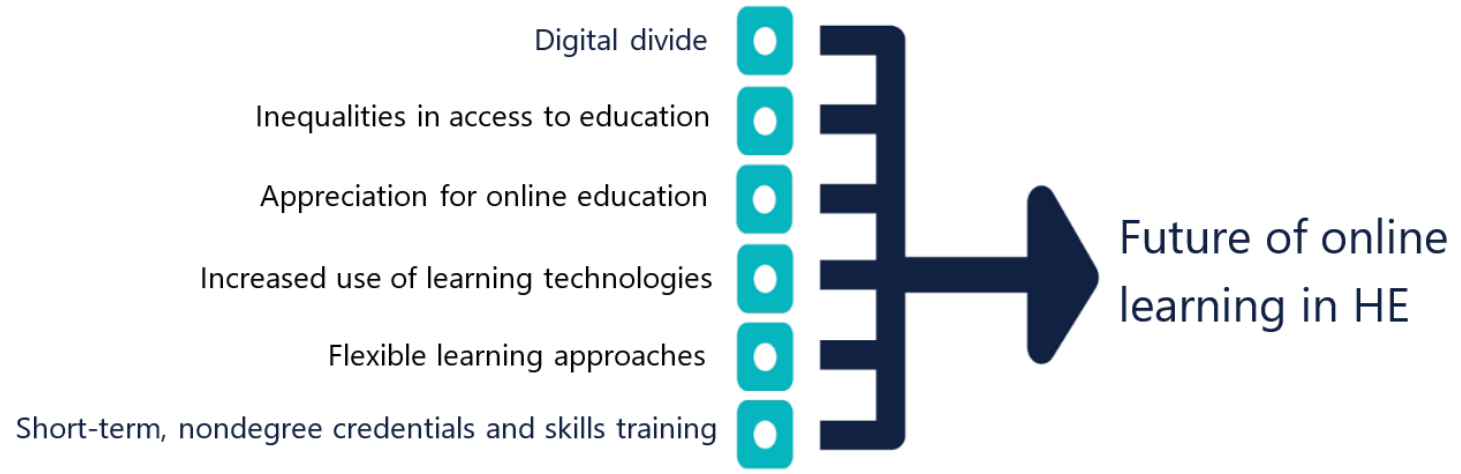

The future of online learning in higher education (HE) will be shaped by many forces. In that regard, without claiming to be exhaustive, this paper highlighted and explored six teaching and learning trends that have been accelerated or disrupted by the coronavirus pandemic. As shown in Figure 5, all these highlighted trends will have an impact on the evolution and the future of online learning and adult education in higher education.

\section{Reference list}

Aslanian, C.B., Fischer, S., \& Rick, K. (2021), Online College Students 2021. Meeting Online Student Demands and Peferences in a Reshaped World. EducationDynamics. https://insights.educationdynamics.com/rs/183-YME-928/images/Online-College-Students-2021.pdf

Baxter, J., Callaghan, G., \& McAvoy, J. (2018). The Context of Online Teaching and Learning: Neoliberalism, Marketization and Online Teaching. In Creativity and Critique in Online Learning (pp. 13-29). Palgrave Macmillan, Cham.

Boeren, E., Roumell, E. A., \& Roessger, K. M. (2020). COVID-19 and the future of adult education: An editorial. Adult Education Quarterly (American Association for Adult and Continuing Education), 70(3), 201-204. https://doi.org/10.1177/0741713620925029

Brammer, S., \& Clark, T. (2020). COVID-19 and management education: Reflections on challenges, opportunities, and potential futures. British Journal of Management, 31(3), 453-456. https://doi.org/10.1111/1467-8551.12425

Cahapay, M. B. (2020). A Reconceptualization of Learning Space as Schools Reopen amid and after COVID-19 Pandemic. Asian Journal of Distance Education, 15(1), 269-276. http://files.eric.ed.gov/fulltext/EJ1289928.pdf

Chawinga, W. D., \& Zozie, P. A. (2016). Increasing access to higher education through open and distance learning: Empirical findings from Mzuzu University, Malawi. The International Review of Research in Open and Distributed Learning, 17(4).

Davis, V. L. (2018). US Federal Policy in Distance Education. In Handbook of Distance Education (pp. 351-365). Routledge.

Donovan, T., \& Bates, T. (2018). Canadian Survey of Online and Digital Learning. https://formationenlignecanada.ca/

Esteban Jr, A. M. (2021). Digital Divide in Times of Pandemic among Teacher Education Students. Open Access Library Journal, 8(04), 1. https://doi.org/10.4236/oalib.1107323 
Evans, T. (2000). Flexible delivery and flexible learning: Developing Flexible Learners? In V. Jakupec \& J. Garrick (Eds). Flexible learning, human resource and organizational development: Putting theory to work, pp. 211-224. Psychology Press.

Fox, K., Bryant, G., Lin, N., Khedkar, N., Nguyen, A., (2021, January 28). Time for Class - COVID-19 Edition Part 3: The Impact of 2020 on Postsecondary Teaching and Learning of Introductory Faculty. Tyton Partners.

Freedman, P., LeBlanc, P. (2021). Let's Make This the 'Year of Stackability.' Credentials must be stackable if we're to educate adult learners successfully (opinion). https://tinyurl.com/bd6ncnyp

Garrett, R., Simunich, B., Legon, R., \& Fredericksen, E. E. (2021). CHLOE 6: Online Learning Leaders Adapt for a PostPandemic World, The Changing Landscape of Online Education, 2021. Retrieved from the Quality Matters website: https://www.qualitymatters.org/qa-resources/resource-center/articles-resources/CHLOE-6-report-2021

Ghasia, M., Machumu, H., \& Smet, E. (2019). Micro-credentials in higher education institutions: An exploratory study of its place in Tanzania. International Journal of Education and Development Using ICT, 15(1). http://ijedict.dec.uwi.edu/viewarticle.php?id=2598

Gierdowski, D., Brooks, C., Galanek, J. (2020). Student Technology Report: Supporting the Whole Student. Educause.Edu. https://library.educause.edu/resources/2020/10/2020-student-technology-report-supporting-the-whole-student

Gnanadass, E., \& Sanders, A. Y. (2018). Gender Still Matters in Distance Education. In Handbook of Distance Education (pp. 79-91). Routledge.

Higher Education Strategy Associates - HESA (2021, January). The Future of Learning: A Report from the Front Line.

Janak, H. (2020, September 21). The state of adult education in the age of COVID-19. Education and Human Development. https://tinyurl.com/yckzvjkh

Johnson, N., Seaman, J. and Veletsianos, G. (2021, March 22). Teaching during a pandemic: Spring Transition, Fall Continuation, Winter Evaluation Bay View Analytics: Oakland, CA. https://www.bayviewanalytics.com/reports/teachingduringapandemic.pdf

Kapplinger, B., \& Lichte, N. (2020). "the lockdown of physical co-operation touches the heart of adult education": A delphi study on immediate and expected effects of COVID-19. International Review of Education, 66(5-6), 777-19. https://doi.org/10.1007/s11159-020-09871-w

Kinash, S., Birt, J., \& Judd, M. M. (2018). Is Technology Enabling or Disabling for Diverse Learners Studying Online? In Handbook of Distance Education (pp. 295-310). Routledge.

Lai, J., \& Widmar, N. O. (2021). Revisiting the Digital Divide in the COVID-19 Era. Applied economic perspectives and policy, 43(1), 458-464. https://doi.org/10.1002/aepp.13104

Lederman, D. (2018, November 7). Online Education Ascends. Inside Higher Ed. https://tinyurl.com/2n5abt6d

Lee, K. (2017). Rethinking the accessibility of online higher education: A historical review. The Internet and Higher Education, 33, 15-23. https://doi.org/10.1016/j.iheduc.2017.01.001

Lemoine, P. A., \& Richardson, M. D. (2015). Micro-credentials, nano degrees, and digital badges: New credentials for global higher education. International Journal of Technology and Educational Marketing (IJTEM), 5(1), 36-49. https://doi.org/10.4018/ijtem.2015010104

Li, K. C., \& Wong, B. Y. Y. (2018). Revisiting the definitions and implementation of flexible learning. Innovations in open and flexible education, 3-13. In: Li K., Yuen K., Wong B. (eds) Innovations in Open and Flexible Education. Education Innovation Series. Springer, Singapore. https://doi.org/10.1007/978-981-10-7995-5 1

Nicoll, K. (2008). Discipline and e-learning. Foucault and lifelong learning: Governing the subject, 164-77. New York: Routledge.

OECD. (2020). The potential of online learning for adults: Early lessons from the COVID-19 crisis. OECD Publishing. https://doi.org/10.1787/ee040002-en

Ong, P. (2020). COVID-19 and the Digital Divide in Virtual Learning. https://escholarship.org/content/qt07g5r002/qt07g5r002.pdf 
Öztok, M. (2019). The Hidden Curriculum of Online Learning: Understanding Social Justice through Critical Pedagogy. Routledge.

Pelletier, K., Brown, M., Brooks, D.C., McCormack, M., Reeves, J., Arbino, N., Bozkurt, A., Crawford, S., Czerniewicz, L., Gibson, R., Linder, K., Mason, J. \& Mondelli, V. (2021). 2021 EDUCAUSE Horizon Report: Teaching and Learning Edition. EDUCAUSE Publications.

https://library.educause.edu/-/media/files/library/2021/4/2021 hrteachinglearning.pdf

Picciano, A. G. (2016). Online education policy and practice: The past, present, and future of the digital university. Routledge.

Rapanta, C., Botturi, L., Goodyear, P., Guàrdia, L., \& Koole, M. (2020). Online university teaching during and after the Covid19 crisis: Refocusing teacher presence and learning activity. Postdigital Science and Education, 2(3), 923-945. https://doi.org/10.1007\%2Fs42438-020-00155-y

Smith, K., Jeffery, D., \& Collins, K. (2018). Slowing things down: Taming time in the neoliberal university using social work distance education. Social Work Education, 37(6), 691-704. https://doi.org/10.1080/02615479.2018.1445216

Stanistreet, P., Elfert, M., \& Atchoarena, D. (2020). Education in the age of COVID-19: Understanding the consequences. International Review of Education, 66(5-6), 1-7. https://doi.org/10.1007/s11159-020-09880-9

Stöter, J., Bullen, M., Zawacki-Richter, O., \& von Prümmer, C. (2014). 16 From the Back Door into the Mainstream: The Characteristics of Lifelong Learners. In O. Zawacki-Richter \& T. Anderson (Eds). Online Distance Education, pp. 421-458. https://doi.org/10.15215/aupress/9781927356623.01

Strada, Center for Education Consumer Insights. (2020, December 9). Strada Public Viewpoint: COVID-19 Work and Education Survey, Insights From 2020, Implications for 2021. https://tinyurl.com/4uxtsu97

Wheelahan, L., \& Moodie, G. (2021). Analysing micro-credentials in higher education: a Bernsteinian analysis. Journal of Curriculum Studies, 53(2), 212-228. https://doi.org/10.1080/00220272.2021.1887358

Zayabalaradjane, Z. (2020). COVID-19: Strategies for Online Engagement of Remote Learners. Online Submission, 9:246 (document). https://doi.org/10.7490/f1000research.1117835.1 